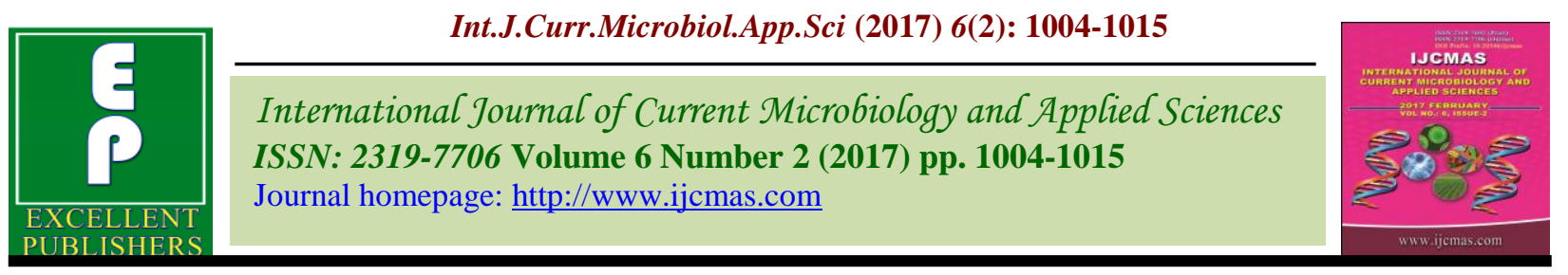

Original Research Article

http://dx.doi.org/10.20546/ijcmas.2017.602.113

\title{
Impact of Chemical Free Bio-Accelerated Climate Resilient Cropping on Lentil (Lens culinaris Medic.) Growth and Yield against Conventional Farming System under Rainfed Condition
}

\author{
Dipen Dahal ${ }^{1}$, J. Ghosh ${ }^{1}$ and Binoy Chhetri $^{2} *$ \\ ${ }^{1}$ Department of Agricultural Entomology, Faculty of Agriculture, Uttar Banga Krishi \\ Viswavidyalaya, Pundibari, Coochbehar-736165, India \\ ${ }^{2}$ Regional Research Station (HZ), Uttar Banga Krishi Viswavidyalaya, Kalimpong-734301, India \\ *Corresponding author
}

\section{A B S T R A C T}

Keywords

Lentil, Bioaccelerated, Conventional, Growth, Yield Attributes, Yield, Uptake.

Article Info

Accepted:

20 January 2017

Available Online:

18 February 2017

\begin{abstract}
A field experiment was conducted at Instructional Farm of Uttar Banga Krishi Viswavidyalaya, West Bengal, India in winter season of 2013 and 2014 to assess the effect of chemical free bio-accelerated and conventional farming system on growth, yield attributes, yield, nutrient uptake, quality and microbial population of lentil. Results revealed that the growths, yield attributes, yield, N, P and $\mathrm{K}$ uptake, quality and microbial population of lentil was recorded higher in chemical free bio-accelerated compared to the conventional farming system. Among the chemical free bio-accelerated farming system pest incidence was found to be lower as compared to the conventional farming system. Lentil produces the average of 0.35 /leaf in bio-accelerated farming and 0.63 /leaf of aphids was calculated in conventional farming system. However, moisture percentage at maturity stage was higher in conventional farming $(74.47 \%)$ and bio-accelerated farming $(73.60 \%)$. The bio-accelerated farming system produces the quality crop restoring the quality of soil health and better grain quality. The better economic returns in bio-accelerated farming also proved its superiority.
\end{abstract}

\section{Introduction}

Lentil (Lens culinaris Medic.) is locally known as Masoor and one of the oldest annual grain legumes consumed and cultivated in the world. Among the pulses, lentil is of special interest with $23.7 \%$ content of grain protein, $59 \%$ carbohydrates, $1.8 \%$ oil, $0.2 \%$ ash and traces of iron calcium, phosphorus and magnesium and seed is a rich source of minerals and vitamins as human food, while the straw serves as high-value animal feed (Rasheed et al., 2010). Being a leguminous crop, lentil can make use of atmospheric $\mathrm{N}_{2}$ to fulfill its $\mathrm{N}$ requirements through biological nitrogen fixation (Badarneh, 1995) and its cultivation enriches nutrient status in soil by adding nitrogen, carbon and organic matter, which promotes sustainable crop production system (Sarker et al., 2004). However, in our country yield potential of lentil far below compared to the other pulse crops. This crop is usually grown on restricted to poor soil, barani conditions and marginal lands without any fertilizer application which is one of the most important causes of low yield. 
There is a direct need to systematically redirect agricultural knowledge, science and technology towards sustainable, biodiversitybased ecological agriculture and the underlying agro-ecological sciences (IAASTD, 2011). This is because it is postulated that the ecological model of agricultural production, which is based on principles that prioritize farmers and traditional knowledge, is climate resilient as well as productive. However, farmer's knowledge to grow a diversity of crops to create the resilience needed to face increased unpredictability in weather patterns. On the other hand, indigenously prepared microbial culture like jiwamrita and organic mulches are the major sources of nutrients in bioaccelerated farming. The practices recently are gaining much popularity to enhance and maintain soil organic status for obtaining a sustainable crop yield (Ravi et al., 2012). So, in this context the approach for chemical free bio-accelerated farming provides a better solution for conjunctive use of natural resources (organic) of plant nutrients for crop productivity as well as sustaining soil health and environment. Considering the above mentioned reason a study on insect, growth, yield and quality of lentil as influence by bioaccelerated farming and conventional farming system.

\section{Materials and Methods}

The field experiment was carried out at Instructional Farm of Uttar Banga Krishi Viswavidyalaya, Coochbehar, West Bengal, India during 2010-11 and 2011-12. The farm is situated at $26^{\circ} 19^{\prime} 86^{\prime \prime} \mathrm{N}$ latitude and $89^{\circ} 23$ '53'E longitude at an elevation of 43.0 $\mathrm{m}$ above mean sea level. The soil of the experimental field was sandy loam in texture with $\mathrm{pH}$ 5.7. The experimental area was divided by two types (treatments) of farming system viz. bio-accelerated and conventional farming. For bio-accelerated farming system indigenous microbial culture (beejamrita) was prepared with fresh cow dung, cow urine, lime and a handful of soil from the bund (uncultivated soil). After sowing, the indigenous microbial culture (jeewamrita) prepared by fresh cow dung $(10 \mathrm{~kg})+$ cow urine (10 litre $)+$ molasses $(2 \mathrm{~kg})+$ pulse dust $(2 \mathrm{~kg})+$ handful of bund soil mixed in water (200 liter for one acre) stirred thrice daily for three days was applied at 15 days interval till grain filling stage. Application was done by spreading diluted microbial culture according to its requirement entirely in the plots at late afternoon hours simply with plastic mug available. The results were analyzed taking consideration of pre harvest parameters like plant height, root length, leaf width and stem girth at 30,60, 90 days after sowing and at harvest where as post harvest parameters were cob length, seed weight, 1000 seed weight (test weight), seed yield $\left(\mathrm{kg} \mathrm{ha}^{-1}\right)$. Estimation of micro-organism population was done by the methods of Waksman and Fred (1922) after the samples were homogenized in mortar with a pestle and sieve through 2-mm sieve. One gram each of organic based and inorganic based soil sample were mixed with $9 \mathrm{ml}$ of sterile distilled water in two different test tube to prepare $10^{-1}$ dilution. These suspensions were used for serial dilution up to $10^{-7}$. One $\mathrm{ml}$ of each suspension from $10^{-5}$ to $10^{-7}$ were plated separately in potato dextrose agar medium and incubated at $28 \pm 1^{\circ} \mathrm{C}$ for $3-5$ days. The moisture percentage was determined by following the procedure of Paul et al., (1992).

Moisture \% =

Weight of fresh leaves - Weight of dry leaves

Weight of fresh leaves

Economic analyses were gross return, net return and benefit cost ratio. The replicated data generated were analyzed statistically 
using statistical package of SAS and determined the probability for significant variation among the treatments.

\section{Results and Discussion}

Effect of treatments on the incidence of aphids (Aphis craccivora Koch)

Maximum number of aphids population was recorded during the month of January and first week of February and low level of aphids population was recorded from $2^{\text {nd }}$ week of February onwards (Table 1).

It was revealed that from the pooled data, maximum level of aphid population reached during $7^{\text {th }}$ standard week (end of February) in both bio-accelerated and conventional farming system (1.87 aphids/leaf and 2.84 aphids/leaf).

The population level then declined gradually and the minimum population was found on $9^{\text {th }}$ standard week ( $1^{\text {st }}$ week of March) in both the farming system $(0.13$ aphids $/ 10 \mathrm{~cm}$ of terminal shoot in bio-accelerated system and 0.37 aphids $/ 10 \mathrm{~cm}$ of terminal shoot in conventional system). This might be due to the lentil is cool season crop and it is highly sensitive to weather condition, especially rainfall, temperature and early frost. Hence aphid generally infested during January to first week of March in this period aphid population gradually increased.

Hossain et al., (2006) reported that the higher aphid population was recorded during the crop sown in December. From the ' $t$ '-test value it was found that aphid population was more in conventional farming than bioaccelerated farming, but was non-significant throughout the observation period from $6^{\text {th }}$ standard week to $9^{\text {th }}$ standard week except, $8^{\text {th }}$ standard week where, the pest population variation was significant (Table 2).
Impact of abiotic factors on the incidence of aphids (Aphis craccivora Koch)

It was recorded that the aphid population was found in the lentil plant on $6^{\text {th }}, 7^{\text {th }}, 8^{\text {th }}$ and $9^{\text {th }}$ standard week with the range of average temperature ranges from $18.41^{\circ} \mathrm{C}$ to $21.28^{\circ} \mathrm{C}$, temperature gradient from 13.25 to 15.41 , average relative humidity from $78.11 \%$ to $60.28 \%$ and relative humidity gradient from $34.36 \%$ to $36.72 \%$. The rainfall was the minimum when the aphid population reached its peak in absence of rainfall though $1.26 \mathrm{~mm}$ of rainfall was recorded during $6^{\text {th }}$ standard week when the population starts to appear in the field. It can therefore be said that, high humidity, moderate temperature and low rainfall are found to be conducive for growth and multiplication of aphid. Multiple regression equation (Table 3 ) revealed that individual weather factors did not show significant impact on the population of lentil aphid in bio-accelerated and conventional farming system but weather parameters in total had definite impact on them.

\section{Effect of treatments on the growth parameters of lentil}

Plant height of lentil highest was recorded under bio-accelerated farming compared to the conventional farming system at all stages of crop growth. The height of plant increased with the advancement of the crop age due to its growth and reached its maximum at harvest irrespective of the treatments tried (Table 4). However, it was revealed that from the pooled data the height of the plant was increased gradually from $10.75 \mathrm{~cm}$ and 10.50 $\mathrm{cm}$ at 30 DAS to $14.58 \mathrm{~cm}$ and $13.68 \mathrm{~cm}$ at 60 DAS and $31.91 \mathrm{~cm}$ and $30.09 \mathrm{~cm}$ at maturity in bio-accelerated and conventional farming. The maximum plant height in bio-accelerated farming system might be due to stimulated biological activities which enhanced the plant growth by improving soil nutrient status, 
secreting plant growth regulators and suppressing aphid populations. Singh and Singh (2014) also reported that the application of organic source of nutrients through farm yard manure or vermicompost to the crop which untimely enhance crop growth. From the ' $t$ '-test value it was revealed that the plant height varied non-significantly in bio-accelerated and conventional farming system at the early stage of crop growth i.e. 30 DAS but the varied significantly with the crop growth i.e. at 60 DAS and at maturity (Table 5). The highest number of branches/plant was recorded at 30 days after sowing in bio-accelerated (3.50) and conventional farming (3.77) branches/ plant. The highest number of branch/plant at maturity was recorded under bio-accelerated (13.85 branches/plant) compared to the conventional farming system (12.65 branches/plant). This might be due to the application of organic sources nutrients like jiwamitra are the store house of plant nutrients which might have improved the physic-chemical as well as biological properties of the soil to enhance the number of branches per plants (Table 4). These results are in conformity with the findings Giri and Joshi (2010) and Sinha et al., (2010). From the ' $t$ '-test value it was revealed that, initially at 30 DAS the branch per plant was nonsignificant between both farming system but, during 60 DAS and at maturity it was significantly different from each other (Table $5)$. However, the root length of the plant was $5.38 \mathrm{~cm}$ and $5.43 \mathrm{~cm}$ at 30 DAS, $11.86 \mathrm{~cm}$ and $11.85 \mathrm{~cm}$ at 60 DAS while, $13.97 \mathrm{~cm}$ and $13.34 \mathrm{~cm}$ at maturity was recorded in bioaccelerated and chemical farming (Table 4). The increased of root length on chemical free bio accelerated farming system might be due to application nutrients like jiwamitra under this fertility levels favoured the root proliferation by stimulating cellular activities and translocation of certain growth stimulating compounds to roots. However,
Sutaria et al., (2010) reported that the extensive root development system with balanced fertilization along with organic in adequate amount would have assisted the efficient absorption and utilization of other nutrients. ' $t$ '-test revealed that root length varied non-significantly between the treatments at all stages of plant growth. However, the average nodules/plant was 7.90 and 6.36 at 30 DAS, 18.11 and 13.93 on 60 DAS and at maturity it was 32.21/plant and 19.96/ plant in bio-accelerated and conventional farming respectively. From the ' $t$ '-test value revealed that the numbers of nodules were found significantly higher in the bio-accelerated system than conventional farming system. The average nodules weight/plant were $3.27 \mathrm{~g} /$ plant in bioaccelerated and $2.23 \mathrm{~g} /$ plant in conventional farming. Weight of the nodules/plant was observed significantly higher in bioaccelerated than conventional farming. Maximum number of nodule per plant and nodules weight in bio-accelerated might be due to availability of macro and micronutrients from applied organic nutrients which improving the micro environment of root growth and number of nodules Singh et al., (2011). ' $\mathrm{t}$ '- test showed that the number of nodules were found significantly higher in the bio-accelerated system than conventional farming system in both the year. Leaf width was $2.26 \mathrm{~cm}$ in bio-accelerated and $2.21 \mathrm{~cm}$ in conventional farming at $30 \mathrm{DAS}, 2.59 \mathrm{~cm}$ in bio-accelerated and $2.67 \mathrm{~cm}$ in conventional farming at 60 DAS and $3.03 \mathrm{~cm}$ and $2.86 \mathrm{~cm}$ in bio-accelerated and conventional farming. ' $t$ 'test revealed that the leaf width on bioaccelerated and conventional farming was non-significant on 30 DAS and at 60 DAS but it was significantly different at maturity. Moisture percentage was always found to be higher in conventional farming (74.47\%) compared to the bio-accelerated farming $(73.60 \%)$ (Table 4). 't'-test revealed that conventional farming plant sample contains 
higher moisture percentage than bioaccelerated farming though the moisture percentage was statistically non-significant (Table 5).

\section{Effect of treatments on yield attributing characters and yield of lentil}

Irrespective of bio-accelerated and conventional farming yield attributes (number of pods per plant, pod length, grain length, seeds per pod, pod weight, test weight and yield) as more in bio-accelerated due to more vigorous growth of the crop which was reflected on yield attributes of lentil. However, from the pooled data the highest number of pods/plant was recorded in bioaccelerated (73.17) and conventional farming (70.42). The length of the pod was $1.36 \mathrm{~cm}$ in bio-accelerated and $1.34 \mathrm{~cm}$ in conventional farming respectively. The highest grain length of $0.36 \mathrm{~cm}$ was recorded in bio-accelerated compared to the $0.34 \mathrm{~cm}$ in conventional farming. Bio-accelerated farming (1.56) was recorded highest number of seeds/pod than conventional farming (1.37). From the pooled data it was revealed that, $0.054 \mathrm{~g} /$ pod in bioaccelerated farming and $0.050 \mathrm{~g} / \mathrm{pod}$ in conventional farming. This might be due to the increased population of microbes which helps mobilization of the nutrients from unavailable form to available form (Table 4). From the ' $t$ '-test analysis showed the number of pods/plant, length of the pod, numbers of seeds per pod, highest grain length and pods weight were significantly higher in bioaccelerated farming than the conventional farming (Table 5). From the pooled data highest test weight was recorded under bioaccelerated farming $(16.37 \mathrm{~g})$ compared to the conventional farming system (16.15g). The organic sources like Jiwamitra and other organic source of nutrients are the store house of plant nutrients which might have improved the physic-chemical as well as biological properties of the soil to enhance crop yield. Application of only chemical fertilizers for the soils which deprived all the these advantages necessary for more production of functioning leaves, greater accumulation of carbohydrates, protein and their translocation to the reproductive organs, which in turn increased the number of pods per plant, number of seeds per pods and other associated yield attributing parameters (Table 5). These results are in conformity with the findings of Kumar et al., (2010), Dekhane et al., (2011) and Sharma and Verma (2011). From the 't'test analysis suggested that the test weight was found to be non significant between the bio-accelerated farming and conventional farming systems. The highest yield was recorded under bio-accelerated farming $(1994.80 \mathrm{~kg} / \mathrm{ha})$ compared to the in conventional farming systems (1933.30 $\mathrm{kg} / \mathrm{ha}$ ) (Table 4). This might be due to the fact that soils of bio-accelerated farming system contained enough indigenous microbial population to allow maximum growth and yield). These results are in conformity with the finding of Kumar and Kumar (2006). The ' $t$ '-test revealed that the overall yield per hectare was higher in the bio-accelerated farming than the conventional farming though the difference was minimum and nonsignificant (Table 5).

\section{Effect of treatments on availability and uptake of nutrients}

Nutrient status of the soil was analyzed and found that the availability of nitrogen was lower in bio-accelerated farming system as compare to the conventional farming system during both the years of experimentation. The highest availability of nitrogen was recorded under conventional farming system (127.65 $\mathrm{kg} / \mathrm{ha}$ ) compare to the bio-accelerated farming system (120.18 kg/ha) (Table 6). This might be due to the continuous application of inorganic fertilizers on conventional farming system increased the nitrogen availability in soil. 
Table.1 Effect of treatments on the incidence of aphids (Aphis craccivora Koch)

\begin{tabular}{ccccccc}
\hline & \multicolumn{9}{c}{ Aphids/leaf } \\
\cline { 2 - 7 } Std wk & \multicolumn{2}{c}{$\mathbf{1}^{\text {st }}$ year } & \multicolumn{2}{c}{$\mathbf{2}^{\text {nd }}$ year } & \multicolumn{2}{c}{ Pooled } \\
\cline { 2 - 7 } & $\mathbf{B F}$ & $\mathbf{C F}$ & $\mathbf{B F}$ & $\mathbf{C F}$ & $\mathbf{B F}$ & $\mathbf{C F}$ \\
\hline 2 & 0.00 & 0.00 & 0.00 & 0.00 & 0.00 & 0.00 \\
3 & 0.00 & 0.00 & 0.00 & 0.00 & 0.00 & 0.00 \\
4 & 0.00 & 0.00 & 0.00 & 0.00 & 0.00 & 0.00 \\
5 & 0.00 & 0.00 & 0.00 & 0.00 & 0.00 & 0.00 \\
6 & 2.00 & 3.13 & 0.07 & 0.33 & 1.03 & 1.73 \\
7 & 2.93 & 4.80 & 0.80 & 0.87 & 1.87 & 2.84 \\
8 & 0.13 & 1.87 & 1.40 & 2.13 & 0.77 & 2.00 \\
9 & 0.00 & 0.13 & 0.27 & 0.60 & 0.13 & 0.37 \\
10 & 0.00 & 0.00 & 0.00 & 0.00 & 0.00 & 0.00 \\
11 & 0.00 & 0.00 & 0.00 & 0.00 & 0.00 & 0.00 \\
12 & 0.00 & 0.00 & 0.00 & 0.00 & 0.00 & 0.00 \\
\hline Mean & & & & & $\mathbf{0 . 3 5}$ & $\mathbf{0 . 6 3}$ \\
\hline
\end{tabular}

Table.2 ' $t$ '-test analysis on effect of cultivation practices of lentil on the incidence of aphid

\begin{tabular}{ccccc}
\hline $\begin{array}{c}\text { Standard } \\
\text { week }\end{array}$ & 6th & 7th & 8th & 9th \\
\hline t-value & -1.46 & -1.40 & -5.01 & -2.02 \\
& & & & \\
Pr>t & $\begin{array}{c}0.15 \\
54\end{array}$ & $\begin{array}{c}0.17 \\
14\end{array}$ & $\begin{array}{c}<.000 \\
1\end{array}$ & 0.0524 \\
\hline
\end{tabular}

Table.3 Regression analyses of different weather parameters with pest

\begin{tabular}{cclc}
\hline Pest & Treatments & \multicolumn{1}{c}{ Equation } & \multicolumn{1}{c}{$\mathbf{R}^{2}$} \\
\hline \multirow{3}{*}{ Aphid } & $\begin{array}{c}\text { Bio-accelerated } \\
\text { farming }\end{array}$ & $\begin{array}{l}\mathrm{Y}=-2.794+0.055 \mathrm{x}_{1}+0.049 \mathrm{x}_{2}+0.013 \mathrm{x}_{3}+ \\
0.014 \mathrm{x}_{4}-0.097 \mathrm{x}_{5}\end{array}$ & 0.136 \\
& $\begin{array}{c}\text { Conventional } \\
\text { farming }\end{array}$ & $\begin{array}{l}\mathrm{Y}=-3.502+0.104 \mathrm{x}_{1}+0.067 \mathrm{x}_{2}+0.008 \mathrm{x}_{3}+ \\
0.020 \mathrm{x}_{4}-0.228 \mathrm{x}_{5}\end{array}$ & 0.189 \\
& &
\end{tabular}

Where, $\mathrm{x}_{1}=$ average temperature, $\mathrm{x}_{2}=$ temperature gradient, $\mathrm{x}_{3}=$ average relative humidity, $\mathrm{x}_{4}=$ relative humidity gradient, $\mathrm{x}_{5}=$ rainfall 
Table.4 Influence of cultivation practices on plant parameters of lentil at different stages

\begin{tabular}{|c|c|c|c|c|c|c|c|}
\hline \multirow[t]{2}{*}{ Parameters } & \multirow{2}{*}{$\begin{array}{c}\text { Stage of } \\
\text { observatio } \\
n\end{array}$} & \multicolumn{2}{|c|}{$\mathbf{1}^{\text {st }}$ year ()} & \multicolumn{2}{|c|}{$2^{\text {nd }}$ year } & \multicolumn{2}{|c|}{ Pooled } \\
\hline & & $\mathbf{B F}$ & $\mathbf{C F}$ & $\mathbf{B F}$ & $\mathbf{C F}$ & $\mathbf{B F}$ & $\mathbf{C F}$ \\
\hline \multirow[t]{3}{*}{ Plant height $(\mathrm{cm})$} & 30 DAS & 11.14 & 10.95 & 10.35 & 10.04 & 10.75 & 10.50 \\
\hline & 60 DAS & 14.69 & 14.17 & 14.47 & 13.19 & 14.58 & 13.68 \\
\hline & At Maturity & 31.63 & 30.88 & 32.19 & 29.30 & 31.91 & 30.09 \\
\hline \multirow[t]{3}{*}{ Root length $(\mathrm{cm})$} & 30 DAS & 4.99 & 4.76 & 5.77 & 6.10 & 5.38 & 5.43 \\
\hline & 60 DAS & 12.24 & 12.05 & 11.48 & 11.64 & 11.86 & 11.85 \\
\hline & At Maturity & 14.34 & 13.82 & 13.59 & 12.86 & 13.97 & 13.34 \\
\hline \multirow[t]{3}{*}{ No. of nodules plant ${ }^{-1}$} & 30 DAS & 8.00 & 5.92 & 7.79 & 6.79 & 7.90 & 6.36 \\
\hline & 60 DAS & 19.80 & 14.40 & 16.42 & 13.46 & 18.11 & 13.93 \\
\hline & At Maturity & 33.83 & 16.58 & 30.58 & 23.33 & 32.21 & 19.96 \\
\hline Nodules weight (gm) & At Maturity & 3.43 & 2.11 & 3.11 & 2.35 & 3.27 & 2.23 \\
\hline \multirow[t]{3}{*}{ Leaf width $(\mathrm{cm})$} & $30 \mathrm{DAS}$ & 2.24 & 2.20 & 2.29 & 2.22 & 2.26 & 2.21 \\
\hline & 60 DAS & 2.54 & 2.52 & 2.65 & 2.82 & 2.59 & 2.67 \\
\hline & At Maturity & 2.96 & 2.74 & 3.10 & 2.98 & 3.03 & 2.86 \\
\hline \multirow[t]{3}{*}{ Branches plant $^{-1}$} & 30 DAS & 3.96 & 3.92 & 3.04 & 3.63 & 3.50 & 3.77 \\
\hline & 60 DAS & 8.54 & 7.79 & 9.04 & 8.25 & 8.79 & 8.02 \\
\hline & At Maturity & 13.42 & 12.88 & 14.29 & 12.42 & 13.85 & 12.65 \\
\hline Moisture percentage (\%) & At Maturity & 76.43 & 77.43 & 70.77 & 71.50 & 73.60 & 74.47 \\
\hline Pods plant ${ }^{-1}$ & At Maturity & 70.33 & 66.58 & 76.00 & 74.25 & 73.17 & 70.42 \\
\hline Pod length $(\mathrm{cm})$ & At Maturity & 1.35 & 1.34 & 1.37 & 1.33 & 1.36 & 1.34 \\
\hline Grains length $(\mathrm{cm})$ & At Maturity & 0.36 & 0.34 & 0.35 & 0.34 & 0.36 & 0.34 \\
\hline Seeds pod ${ }^{-1}$ & At Maturity & 1.54 & 1.42 & 1.59 & 1.33 & 1.56 & 1.37 \\
\hline Pod weight (gm) & At Maturity & 0.053 & 0.050 & 0.056 & 0.050 & 0.054 & 0.050 \\
\hline Test weight (gm) & At Maturity & 16.00 & 15.80 & 16.74 & 16.50 & 16.37 & 16.15 \\
\hline Yield $\left(\mathrm{kg} \mathrm{ha}^{-1}\right)$ & At Maturity & 1903.80 & 1850.20 & 2085.90 & 2016.40 & 1994.80 & 1933.30 \\
\hline
\end{tabular}

BF-Bio-accelerated Farming, CF-Conventional Farming, DAS- Days after sowing

Table.5 ' $t$ '-test analysis on influence of cultivation practices on plant parameters of lentil at different stages

\begin{tabular}{|c|c|c|c|}
\hline Plant parameters & Stage of observation & t-value & $\operatorname{Pr}>t$ \\
\hline \multirow[t]{3}{*}{ Plant height $(\mathrm{cm})$} & $30 \mathrm{DAS}$ & 0.89 & 0.3801 \\
\hline & 60 DAS & 2.94 & 0.0063 \\
\hline & At Maturity & 2.27 & 0.0308 \\
\hline \multirow[t]{3}{*}{ Root length (cm) } & 30 DAS & -0.21 & 0.8389 \\
\hline & 60 DAS & 0.08 & 0.9386 \\
\hline & At Maturity & 1.76 & 0.0881 \\
\hline \multirow[t]{3}{*}{ No. of nodules plant ${ }^{-1}$} & 30 DAS & 3.28 & 0.0026 \\
\hline & 60 DAS & 5.13 & $<.0001$ \\
\hline & At Maturity & 9.09 & $<.0001$ \\
\hline Nodules weight (gm) & At Maturity & 12.34 & $<.0001$ \\
\hline \multirow[t]{3}{*}{ Leaf width $(\mathrm{cm})$} & 30 DAS & 1.37 & 0.1810 \\
\hline & 60 DAS & -1.06 & 0.2990 \\
\hline & At Maturity & 3.50 & 0.0015 \\
\hline \multirow[t]{3}{*}{ Branches plant $^{-1}$} & $30 \mathrm{DAS}$ & -1.83 & 0.0773 \\
\hline & 60 DAS & 4.47 & 0.0001 \\
\hline & At Maturity & 3.45 & 0.0017 \\
\hline Moisture percentage (\%) & At Maturity & -0.75 & 0.4564 \\
\hline Pods plant ${ }^{-1}$ & At Maturity & 0.80 & 0.4296 \\
\hline Pod length $(\mathrm{cm})$ & At Maturity & 2.63 & 0.0133 \\
\hline Grains length $(\mathrm{cm})$ & At Maturity & 5.17 & $<.0001$ \\
\hline Seeds pod ${ }^{-1}$ & At Maturity & 5.11 & $<.0001$ \\
\hline Pod weight (gm) & At Maturity & 9.36 & $<.0001$ \\
\hline Test weight (gm) & At Maturity & 1.12 & 0.2729 \\
\hline Yield $\left(\mathrm{kg} \mathrm{ha}^{-1}\right)$ & At Maturity & 1.19 & 0.0658 \\
\hline
\end{tabular}

DAS- Days after sowing 
Table.6 Nutrients status in the soil and nutrient uptake by lentil

\begin{tabular}{|c|c|c|c|c|c|c|}
\hline \multirow[b]{2}{*}{ Nutrients } & \multicolumn{2}{|c|}{$1^{\text {st }}$ year } & \multicolumn{2}{|c|}{$2^{\text {nd }}$ year } & \multicolumn{2}{|c|}{ Pooled } \\
\hline & BF & CF & BF & $\mathrm{CF}$ & BF & CF \\
\hline $\begin{array}{c}\text { Available Nitrogen } \\
\text { (Kg/hectare) }\end{array}$ & 117.55 & 123.38 & 122.81 & 131.92 & 120.18 & 127.65 \\
\hline $\begin{array}{l}\text { Nitrogen uptake } \\
\text { (Kg/hectare) }\end{array}$ & 55.21 & 70.92 & 53.67 & 70.92 & 54.44 & 70.92 \\
\hline $\begin{array}{l}\text { Available } \\
\text { Phosphorous } \\
\text { (Kg/hectare) }\end{array}$ & 20.56 & 26.29 & 21.41 & 26.67 & 20.99 & 26.48 \\
\hline $\begin{array}{c}\text { Phosphorous uptake } \\
\text { (Kg/hectare) }\end{array}$ & 11.27 & 13.33 & 11.32 & 12.71 & 11.30 & 13.02 \\
\hline $\begin{array}{c}\text { Available Potassium } \\
\text { (Kg/hectare) }\end{array}$ & 60.28 & 70.22 & 50.28 & 61.60 & 55.28 & 65.91 \\
\hline $\begin{array}{c}\text { Potassium uptake } \\
(\mathrm{Kg} / \text { hectare })\end{array}$ & 65.38 & 116.60 & 79.48 & 138.63 & 72.43 & 127.62 \\
\hline
\end{tabular}

Table.7 ' $t$ '-test for nutrient status in the soil and nutrient uptake by lentil

\begin{tabular}{ccccccc}
\hline Nutrients & $\begin{array}{c}\text { Available } \\
\text { Nitrogen } \\
(\text { Kg/hectare })\end{array}$ & $\begin{array}{c}\text { Nitrogen } \\
\text { uptake } \\
(\text { Kg/hectare })\end{array}$ & $\begin{array}{c}\text { Available } \\
\text { Phosphorous } \\
\text { (Kg/hectare) }\end{array}$ & $\begin{array}{c}\text { Phosphorous } \\
\text { uptake } \\
\text { (Kg/hectare) }\end{array}$ & $\begin{array}{c}\text { Available } \\
\text { Potassium } \\
\text { (Kg/hectare) }\end{array}$ & $\begin{array}{c}\text { Potassium } \\
\text { uptake } \\
\text { (Kg/hectare) }\end{array}$ \\
\hline t-value & -3.85 & -12.19 & -6.84 & -4.12 & -5.65 & -15.24 \\
Pr>t & 0.0006 & $<.0001$ & $<.0001$ & 0.0003 & $<.0001$ & $<.0001$ \\
\hline
\end{tabular}

Table.8 Estimation of Phenol and OD Phenol in different cultivation practices ( $\mathrm{mg} \mathrm{g}^{-1}$ )

\begin{tabular}{ccccccc}
\hline & \multicolumn{2}{c}{$\mathbf{1}^{\text {st }}$ year } & \multicolumn{2}{c}{$\mathbf{2}^{\text {nd }}$ year } & \multicolumn{2}{c}{ Pooled } \\
\cline { 2 - 7 } Observation & BF & CF & BF & CF & BF & CF \\
\hline Phenol 30 DAS $\left(\mathbf{m g ~ g}^{-1}\right)$ & 0.12 & 0.14 & 0.17 & 0.16 & 0.15 & 0.15 \\
Phenol at maturity $\left.\mathbf{( m g ~ g}^{-1}\right)$ & 6.28 & 6.52 & 5.90 & 5.80 & 6.09 & 6.16 \\
OD Phenol 30 DAS $\left(\mathbf{m g ~ g}^{-1}\right)$ & 0.01 & 0.01 & 0.02 & 0.02 & 0.02 & 0.02 \\
OD Phenol at maturity (mg & 0.19 & 0.17 & 0.15 & 0.16 & 0.17 & 0.16 \\
$\left.\mathbf{g}^{-1}\right)$ & & & & & & \\
\hline
\end{tabular}

BF-Bio-accelerated, CF-Conventional Farming, DAS-Days after sowing

Table.9 ' $t$ '-table for phenol and OD phenol

\begin{tabular}{ccccc}
\hline Observation & $\begin{array}{c}\text { Phenol } \\
\text { (30 DAS) }\end{array}$ & $\begin{array}{c}\text { Phenol } \\
\text { (at maturity) }\end{array}$ & $\begin{array}{c}\text { OD Phenol } \\
\text { (30 DAS) }\end{array}$ & $\begin{array}{c}\text { OD Phenol } \\
\text { (at maturity) }\end{array}$ \\
\hline $\begin{array}{c}\text { t-value } \\
\text { Pr }>\mathbf{t}\end{array}$ & -0.31 & -0.40 & -0.40 & 0.45 \\
& 0.7608 & 0.6195 & 0.6886 & 0.6581 \\
\hline
\end{tabular}

DAS-Days after sowing 
Table.10 Estimation of micro-organism in soil (cfu)

\begin{tabular}{ccccccc}
\hline & \multicolumn{2}{c}{$\mathbf{1}^{\text {st }}$ year } & \multicolumn{2}{c}{$\mathbf{2}^{\text {nd }}$ year } & \multicolumn{2}{c}{ Pooled } \\
\cline { 2 - 7 } OBSERVATIONS & $\mathbf{B F}$ & $\mathbf{C F}$ & $\mathbf{B F}$ & $\mathbf{C F}$ & $\mathbf{B F}$ & $\mathbf{C F}$ \\
\hline Microbes (before sowing) & 83.50 & 35.75 & 92.88 & 39.25 & 88.19 & 37.50 \\
Microbes (at maturity) & 112.63 & 26.25 & 104.38 & 31.38 & 108.50 & 28.81 \\
\hline
\end{tabular}

BF-Bio-accelerated, CF-Conventional Farming, cfu-colony forming unit

Table.11 ' $t$ '-test analysis for estimation of micro-organism in soil

\begin{tabular}{ccc}
\hline OBSERVATIONS & Microbes (before sowing) & Microbes (at maturity) \\
\hline $\mathbf{t}-$ value & 14.73 & 28.98 \\
Pr $>\mathbf{t}$ & $<.0001$ & $<.0001$ \\
\hline
\end{tabular}

However, Ginting et al., (2003) reported that the continuous application of organic manures increases the level of $\mathrm{N}, \mathrm{P}$ and $\mathrm{K}$, in the soil. Singh et al., (2008) reported that the application of FYM, vermicompost and green leaf manures in releasing $\mathrm{N}$ and improving $\mathrm{N}$ availability in soil. Hence, the ' $t$ '- test of statistical analysis it revealed that, nitrogen availability was similar between the bioaccelerated and conventional farming plots and was found to be non-significant (Table 7). From the pooled data suggested that conventional farming recorded higher available phosphorous $(26.48 \mathrm{~kg} / \mathrm{ha})$ than bio-accelerated farming $(20.99 \mathrm{~kg} / \mathrm{ha})$.

This might be due to the addition of organic manure or their different combinations, favored the availability of higher phosphorus in soil (Table 6). From the ' $t$ '- test analyzed method and it showed that conventional farming were significantly higher phosphorous than bio-accelerated farming (Table 7). Available potassium in the soil was also less in the bio-accelerated farming than conventional farming. Pooled data showed that available potassium of $55.28 \mathrm{~kg} / \mathrm{ha}$ in bio-accelerated and $65.91 \mathrm{~kg} / \mathrm{ha}$ in conventional farming were recorded (Table 6). From the t-test statistical analysis, it was confirmed that, availability of potassium was highly significant between the treatments i.e. potassium was higher in conventional farming than bio-accelerated farming (Table 7).

\section{Uptake}

Nutrient uptake by the lentil plant was measured at maturity and was always higher in the conventional farming than bioaccelerated farming. Pooled data also revealed that uptake of nitrogen $(54.44 \mathrm{~kg} / \mathrm{ha})$ was recorded in bio-accelerated farming while it was $70.92 \mathrm{~kg} / \mathrm{ha}$ in conventional farming (Table 6). Hence the t-test analyzed showed that conventional farming was significantly higher compared to bio-accelerated as far as the nitrogen uptake is concerned. Uptake of phosphorous was also similar to nitrogen as conventional was higher than bio-accelerated farming. From the pooled data, the uptake of phosphorous was $11.30 \mathrm{~kg} / \mathrm{ha}$ in bioaccelerated farming and (13.02 kg/ha) uptake of phosphorous in conventional farming. The results showed that uptake of phosphorous were significantly higher in conventional farming than bio-accelerated farming. ' $t$ '-test also revealed that the uptake of phosphorous was higher in conventional than in bioaccelerated farming. Irrespective of 
treatments tried potassium uptake was higher in conventional than bio-accelerated farming. The average data of the two year study revealed the same consequences as 72.43 $\mathrm{kg} / \mathrm{ha}$ and $127.62 \mathrm{~kg} / \mathrm{ha}$ of potassium uptake was recorded in bio-accelerated farming and conventional farming respectively (Table 6). This might be due the increased growth, nutrient influx and photosynthetic rate resulted in more absorption and translocation of these nutrients to the grain and stover. Results showed that conventional farming uptake of potassium was highly significant than bio-accelerated farming (Table 7).

\section{Effect of treatments on the quality parameters of phenol and OD phenol}

The quality parameters like phenol and OD phenol estimation. From the pooled mean data revealed that phenol $(0.15 \mathrm{mg} / \mathrm{g})$ and $\mathrm{OD}$ phenol $(0.02 \mathrm{mg} / \mathrm{g})$ in bio-accelerated farming was at par with conventional farming at 30 DAS. While, at maturity, $6.09 \mathrm{mg} / \mathrm{g}$ of phenol and $0.17 \mathrm{mg} / \mathrm{g}$ of OD phenol was recorded under bio-accelerated farming and $6.16 \mathrm{mg} / \mathrm{g}$ of phenol with $0.16 \mathrm{mg} / \mathrm{g}$ of OD phenol was recorded under conventional farming system (Table 8).

This might be due to the combined application of jiwamitra along with mulch materials significantly influenced the supplying of plant nutrients and also secrete enzymes and other non-nutrient substances also having PGR activity that promote plant growth in balanced manner and induce resistance to the plant against pests and diseases by enhancing the activity of phenolic compounds, enzymes etc. and through balancing the level of nutrient. Organic manure and straw mulch incorporation in soil improved fertility status of soil which ultimately enhanced the microbial multiplication (She 2008). After analyzing the data using ' $t$ '-test, it was found to be nonsignificant between the treatments (Table 9).

\section{Effect of treatment on estimation of micro- organism (cfu):}

The application of organics manures i.e., jiwanmrita recorded significantly higher number of microbial population in the soil in bio-accelerated farming than the conventional farming. From the pooled data analysis revealed that 88.19 microbes in bioaccelerated and 37.50 microbes in conventional farming before sowing which increased up to 108.51 and decreased to 28.82 in bio-accelerated and conventional farming respectively at the stage of maturity (Table 10). This might be due the higher population of microbes helped in better decomposition of organics and mulch materials, which resulted in better release of nutrients and conservation of more moisture throughout the crop growing period resulted in higher yields as that of conventional treatments. In addition to mineralization, they also supplying plant nutrient and also secrete enzymes. Indigenous microbial culture may act as medium for the growth of beneficial microbes and solutions provide nutrients, proteins, carbonates, amino acids and vitamins as a catalyst in the digestion of organic wastes. Similar findings were reported by Palekar (2001); Yadav and Mowade (2004) and Babalad (2008). 't'-test analysis showed that microbial population was significantly higher in bio-accelerated farming over conventional farming (Table 11).

\section{References}

Babalad, H.B., Sreenivasa, M.N., Patil, R.K. and Palakshappa, M.G. 2008. Organic farming - A Scientific Approach for Sustainable Production and Environment Protection. Soil fertility for organic horticulture, Institute of Organic Farming, University of Agricultural Sciences, Dharwad pp. 8691. 
Badarneh, D. M. D. 1995. Magnitude of nitrogen fixation by lentil at different rates of phosphorous using $15 \mathrm{~N}$ technique. J. Agronomy and Crop Sci., 175: 7-14.

Dekhane, S.S., Khafi, H.R., Raj, A.D. and Parmar, R.M. 2011. Effect of bio fertilizer and fertility levels on yield, protein content and nutrient uptake of cowpea (Vigna unguiculata L.. Legume Res., 34(1): 51 - 54.

Ginting, D., Kessavalou, A., Eghball, B. and Doran, J.W. 2003. Greenhouse gas emissions and soil indicators four years after manure compost application. $J$. Environ. Qual., 32: 23-32.

Giri, N. and Joshi, N.C. 2010. Growth and yield response of chick pea (Cicer arietinum) to seed inoculation with Rhizobium sp. Nature \& Sci., 8(9): 232236.

Hossain Altaf, M.D., J. Annatul, F. Erdous and Salim, M.M.R. 2006. Relative Abundance and Yield Loss Assessment of Lentil Aphid, Aphis craccivora Koch in Relation to Different Sowing Dates. J. Agric. \& Rural Dev., 4(1\&2): 101106.

IAASTD. 2009. Agriculture at a crossroads, International Assessment of Agricultural Knowledge, Science and Technology for Development (Island Press, Washington DC: IAASTD, www.agassessment.org. in.

Kumar, A., Reena, N.B., Kumar, J. and Jamwal, B.S. 2010. Response of large seeded lentil to seed rate, phosphorus and FYM application in sub-tropical kandi-belt of Jammu and Kashmir. $J$. Food Legumes, 23(1): 44- 46.

Kumar, S. and Kumar, R. 2006. Effect of farm yard manure, phosphorus levels and biofertilizer on productivity of lentil. Crop Res., 31(3): 370-372.

Palekar, S. 2001. The Philosophy of Spiritual Farming-Vol.1.

Amrawati,
Maharashtra, India.

Paul, D.C., Subba Rao, G. and Deb, D.C. 1992. Impact of dietary moisture on nutritional indices and growth of Bombyx mori and Concomitant larval duration. J. Insect Physiol., 38: 229.

Rasheed, M., Jilani, G., Shah, I.A., Najeeb, U. and Iqbal, T. 2010. Genotypic variants of lentil exhibit differential response to phosphorus fertilization for physiological and yield attributes. Acta Agra Scan Section-B: Soil Plant Sci., 60: 485-493.

Ravi, N., Basavarajappa, S.R., Chandrashekar, C.P., Harlapur, S.I., Hosamani, M.H. and Manjunatha, M.V. 2012. Effect of integrated nutrient management on growth and yield of quality protein maize. Karnataka $J$. Agric. Sci., (3): 395-396.

Sarker, A., Erskine, W., Saxena, M.C. 2004. Global perspective on lentil improvement. In: Masood A., Singh B., Kumar S., and Dhar V. eds) Pulses in new perspective. Indian Institute of Pulses Research, Kanpur, India. pp. 543-550.

Sharma, R. and Verma, M.L. 2011. Effect of Rhizobium, farmyard manure and chemical fertilizers on sustainable production and profitability of rajmash (Phaseolus vulgaris L.) and soil fertility in dry temperate region of Northwestern Himalayas. Legume Res., 34(4): $251-258$.

She, D.L., Wang, K.R., Xie, X.L., Chen, M. and Lin, Y.H. 2008. Impact of incorporation of rice straw into the soil on soil fertility and yield. Chinese $J$. Economic Agri., 16(1): 100-104.

Singh, A.B., Saha, J.K. and Gosh, P.K. 2008. Effect of nutrient management practices on soybean (Glycine max)-chickpea (Cicer arietinum) cropping systems for improving seed yield, quality and soil biological health under rainfed 
condition. Indian J. Agric. Sci., 78(6): 485-489.

Singh, G., Hari, R., Sekhon, H.S., Aggarwal, N. and Khanna Veena. 2011. Effect of nutrient management on nodulation, growth and yield of lentil (Lens culinaris Medik.) genotypes. American Eurasian J. Agronomy, 4(3): 46-49.

Singh, Dashrath and Singh, R.P. 2014. Effect of integrated nutrient management on growth, physiological parameters and productivity of lentil (Lens culinaris Medik.. Int. J. Agric. Sci., 10(1): 175178.

Sinha, J., Biswas, C.K., Ghosh, A. and Saha,
A. 2010. Efficacy of vermicompost against fertilizers on Cicer and Pisum on population diversity of $\mathrm{N}_{2}$ fixing bacteria. J. Environ. Bio., 31(3): 287292.

Sutaria, G.S., Kabari, K.N., Vora, V.D., Hirpara, D.S. and Padmani, D.R. 2010. Response of legume crops to enriched compost and vermicompost on Ustochrept under rainfed Agriculture. Legume Res., 33(2): 128-130.

Yadav, A.K. and Mowade, S.M. 2004. Organic manures and compost. In: Organic Farming - A Ray of Hope for Indian Farmer.

\section{How to cite this article:}

Dipen Dahal, J. Ghosh and Binoy Chhetri. 2017. Impact of Chemical Free Bio-Accelerated Climate Resilient Cropping on Lentil (Lens culinaris Medic.) Growth and Yield against Conventional Farming System under Rainfed Condition. Int.J.Curr.Microbiol.App.Sci. 6(2): 1004-1015. doi: http://dx.doi.org/10.20546/ijcmas.2017.602.113 